\title{
The quality of life of disease-free Brazilian breast cancer survivors
}

\author{
A QUALIDADE DE VIDA DE BRASILEIRAS SOBREVIVENTES AO CÂNCER DE MAMA \\ LA CALIDAD DE VIDA DE BRASILEÑAS SOBREVIVIENTES DEL CÁNCER DE MAMA Renata Cristina Ribeiro Gonçalves ${ }^{4}$, Daniella Reis Barbosa Martelli ${ }^{5}$, Marise Fagundes Silveira ${ }^{6}$, Hercílio Martelli Júnior ${ }^{7}$ \\ Priscila Bernardina Miranda Soares ${ }^{1}$, Jair Almeida Carneiro ${ }^{2}$, Leandro Augusto Rocha ${ }^{3}$,
}

\begin{abstract}
The objective of this study was to compare the quality of life of women who survived breast cancer and women who have not had the disease, and to identify associated factors. It is cross-sectional study in which the comparison group includes survivors of breast cancer aged between 40 and 69 years. One hundred and fifty-four women were included, 70 with breast cancer and 84 without the disease. The SF-36 was used to evaluate quality of life. The chi-square test and multivariate linear models were used to compare the groups. The estimated mean physical and mental components were significantly better for the group who survived the disease (51.10 and 52.25, respectively) compared to the group without cancer (47.26 and 47.93 , respectively). The study indicates that survivors of breast cancer had a better quality of life compared to women without the disease.
\end{abstract}

\section{DESCRIPTORS}

Breast neoplasms

Quality of life

Questionnaire

Oncologic nursing

\section{RESUMO}

O objetivo deste estudo foi comparar a qualidade de vida de mulheres que sobreviveram ao câncer de mama e de mulheres que não tiveram a doença, e identificar os fatores associados. Trata-se de um estudo transversal no qual o grupo de comparação envolve as sobreviventes de câncer de mama com idade entre 40 e 69 anos. Foram incluídas 154 muIheres, 70 sobreviventes do câncer de mama e 84 sem a doença. O questionário SF-36 foi utilizado para avaliar a qualidade de vida. $O$ teste Qui-Quadrado e os modelos lineares multivariados foram utilizados para comparar os grupos. A média estimada dos componentes físicos e mentais foi significativamente melhor para o grupo que sobreviveu à doença (51,10 e 52,25, respectivamente) quando comparado ao grupo sem câncer $(47,26$ e 47,93, respectivamente). 0 estudo indicou que as sobreviventes do câncer de mama tinham melhor qualidade de vida quando comparadas a mulheres sem a doença.

\section{DESCRITORES}

Neoplasias da mama

Qualidade de vida

Questionários

Enfermagem oncológica

\section{RESUMEN}

Se apuntó a comparar la calidad de vida de mujeres sobrevivientes al cáncer de mama con la de mujeres que no sufrieron la enfermedad, e identificar los factores asociados. Estudio transversal en el que el grupo de comparación envuelve a las sobrevivientes de cáncer de mama con entre 40 y 69 años. Fueron incluidas 154 mujeres, 70 sobrevivientes del cáncer de mama y 84 no afectadas. El cuestionario SF-36 fue utilizado para evaluar la calidad de vida. El test Chi-cuadrado y los modelos lineales multivariados fueron utilizados en la comparación de los grupos. La media estimada de los componentes físicos y mentales fue significativamente mejor para el grupo que sobrevivió a la enfermedad (51,10 y 52,25 , respectivamente), en comparación al grupo sin cáncer $(47,26$ y 47,93, respectivamente). El estudio indicó que las sobrevivientes al cáncer de mama tenían mejor calidad de vida comparadas con aquellas que no padecieron la enfermedad.

\section{DESCRIPTORES \\ Neoplasias de la mama \\ Calidad de vida \\ Cuestionarios \\ Enfermería oncológica} ${ }^{1}$ Medical Oncologist at Santa Casa, Montes Claros. Montes Claros, MG, Brazil. priscilamirandasoares@yahoo.com ${ }^{2}$ Student in Health Science,
Universidade Estadual de Montes Claros. Montes Claros, MG, Brazil. jairjota@yahoo.com.br ${ }^{3}$ Medicine School Student, Faculdades Unidas do Norte
de Minas. Montes Claros, MG, Brazil. leandro_rocha_64@hotmail.com ${ }^{4}$ Nurse in the Oncology Department of Santa Casa de Misericórdia, Montes
Claros, MG, Brazil. renagoncalves@yahoo.com.br ${ }^{5}$ Master in Health Science, Universidade Estadual de Montes Claros. Montes Claros, MG, Brazil.
daniellareismartelli@yahoo.com.br ${ }^{6}$ Doctor, PhD in Health Science. Post Graduate Program in Health Science, Universidade Estadual de Montes Claros.
Montes Claros, MG, Brazil. ciaestatistica@yahoo.com.br ${ }^{7}$ Doctor, PhD in Health Science. Post Graduate Program in Health Science, Universidade Estadual
de Montes Claros. Montes Claros, MG, Brazil. hmjunior2000@yahoo.com 


\section{INTRODUCTION}

Breast cancer $(\mathrm{BC})$ is the most common malignancy among women, comprising $22 \%$ of all cases worldwide ${ }^{(1)}$. It has been reported that over one million women are diagnosed annually ${ }^{(2)}$. With the development of techniques for early diagnosis and more effective treatment, the number of cancer survivors in the long term has grown exponentially over the past 20 years $^{(3)}$. The most recent survivorship data from the National Cancer Institute indicate there are over 11.4 million North American cancer survivors, and that $23 \%$ of all cancer survivors in that country are BC survivors ${ }^{(4)}$.

Over the last two decades, could be observed reduction in rates of mortality from breast cancer and cervix in countries of Europe and North America ${ }^{(5-6)}$. However, the situation has been different in developing countries. In Latin America, BC mortality has increased, and cervical cancer, although declining mortality in some countries, it is still responsible for expressive number of deaths in women ${ }^{(7)}$. In Brazil, studies, of trend of mortality from $B C$ and cervix are concentrated in capital cities or States of the Federation, being little known mortality profile these causes in midsized cities ${ }^{(8-11)}$. Recently, it was demonstrated that $B C$ was the main cause of cancer-related death for women in Juiz de Fora, Brazil. Trend analysis using the polynomial regression model showed a decrease in mortality due to uterine cervical cancer $(p=0.001)$ and an increase in mortality due to breast cancer $(p=0.035)$ over the course of the time series ${ }^{(12)}$.

With this rise in survival rates, the interest of researchers and health professionals has greatly increased concerning the impact of chronic diseases, particularly cancer, and their treatments on the quality of life (QOL) of these survivors ${ }^{(13)}$. Several studies linking BC and QOL have shown that the diagnosis and treatments can have social, physical, emotional and psychological repercussions which affect women with breast cancer, which may contribute to a wide variety of side effects that are closely related to poor QOL outcomes ${ }^{(14-16)}$. Nevertheless, other studies which have assessed QOL in women with $\mathrm{BC}$ in different socio-cultural contexts have shown that as the years pass, the QOL of women with $\mathrm{BC}$ becomes comparable to that of women without $B C^{(17-18)}$. Notes that there are few studies assessing the QOL in Brazilian women BC survivors ${ }^{(19)}$.

Considering that sociodemographic and clinical differences may influence $Q O L$, this study aims to compare the $\mathrm{QOL}$ of Brazilian women who have survived $\mathrm{BC}$ with that of women without $B C$.

\section{METHOD}

A cross-sectional study was carried out with one group of $\mathrm{BC}$ survivors and one group without cancer for comparison. It included 154 women, 70 with breast cancer and 84 without cancer. BC group was selected from private (49 women) and public services ( 21 women) in the North of Minas Gerais (Brazil). The participants without cancer were selected from among teaching staff, public servants, housewives and autonomous women. Inclusion criteria for BC group: age 40-69 years, not currently undergoing any cancer treatment for at least a year, and without history of other malignant tumors. Inclusion criteria for control group: age 40-69 years, without history of cancer.

All participants were interviewed in order to assess their socio-demographic and clinical features such as age, parity, marital status, ethnicity and age at menarche. Clinical characteristics of the BC group included tumor stage, histopathological type, whether they had chemotherapy or radiation therapy, type of surgery, and the time elapsed since $\mathrm{BC}$ diagnosis.

Clinical and socio-demographic characteristics were compared between the groups. QOL was assessed using the Medical Outcomes Study 36-item Short-Form Health Survey (SF-36) questionnaire, a generic tool for evaluating $\mathrm{QOL}^{(20)}$, with eight components condensed into two summaries: a physical component summary (PCS) and a mental component summary (MCS). The questionnaires were administered by one of the investigators through interviews. Data were transferred to SPSS $^{\circ}$ 17.0. Women without cancer and with $\mathrm{BC}$ were compared using the chi-square test. Measurements were performed to describe the eight dimensions of the SF-36 as well as summarising physical and mental components through univariate analysis. Multivariate generalised linear models were used in order to analyse data. These statistical models were used to identify the factors that had affected the subjects' QOL, with adjustments made for confounding variables. A p-value of 0.05 was considered statistically significant. The study was approved by the Research Ethics Board of the University. Each interviewee signed an informed consent form before the interview (\# 1957/2010).

\section{RESULTS}

Table 1 presents socio-demographic and clinical features of the 154 participants. In the BC group, stage II was more frequently found (55.7\%). Mastectomies had been performed on $55.7 \%$. $44.3 \%$ had undergone breast conservation therapy and $18.6 \%$ of these women had postmastectomy breast reconstruction. Most of the group had undergone chemotherapy $(81.4 \%)$. It 
was observed that more than $75.0 \%$ of this group had been diagnosed at least five years beforehand. The QOL scores are shown in Table 2. The highest QOL scores among women who had survived $\mathrm{BC}$ were observed in terms of physical functioning components (82.9) and social functioning (87.7), while role-physical (69.9) and vitality (73.9) scored the lowest. The highest QOL sco- res among women without cancer were found in terms of physical functioning components (79.8) and social functioning (73.7), while role-physical (56.5) and vitality (62.6) scored the lowest. Mean PCS and MCS scores were 50.3 and 53.9 , respectively for women with $\mathrm{BC}$; for the women without cancer, these scores were 47.6 and 47.9 , respectively.

Table 1 - The socio-demographic and clinical characteristics of BC survivors and women without cancer - Montes Claros, MG, Brazil, 2011

\begin{tabular}{|c|c|c|c|c|c|}
\hline \multirow{2}{*}{ Characteristics } & \multicolumn{2}{|c|}{ With breast cancer } & \multicolumn{2}{|c|}{ Without breast cancer } & \multirow{2}{*}{ *p-valuc } \\
\hline & $\mathbf{N}$ & $\%$ & $\mathbf{N}$ & $\%$ & \\
\hline \multicolumn{6}{|l|}{ Age (years) } \\
\hline $40-49$ & 20 & 28.6 & 39 & 46.4 & \multirow{3}{*}{0.004} \\
\hline $50-59$ & 27 & 38.6 & 35 & 41.7 & \\
\hline $60-69$ & 23 & 32.9 & 10 & 11.9 & \\
\hline \multicolumn{6}{|l|}{ Ethnicity } \\
\hline White & 58 & 82.9 & 28 & 33.3 & \multirow{2}{*}{0.000} \\
\hline Non white & 12 & 17.1 & 56 & 66.7 & \\
\hline \multicolumn{6}{|l|}{ Marital status } \\
\hline Married/living with partner & 56 & 80.0 & 49 & 58.3 & \multirow{2}{*}{0.007} \\
\hline Single/separated/widow & 14 & 20.0 & 35 & 41.7 & \\
\hline \multicolumn{6}{|l|}{ Menopausal status } \\
\hline Pre-menopause & 9 & 12.9 & 43 & 51.2 & \multirow{2}{*}{0.000} \\
\hline Post-menopause & 61 & 87.1 & 41 & 48.8 & \\
\hline \multicolumn{6}{|l|}{ Tumor Stage } \\
\hline $0 / \mathrm{I}$ & 19 & 27.1 & & & \\
\hline II & 39 & 55.7 & & & \\
\hline III/IV & 12 & 17.1 & & & \\
\hline \multicolumn{6}{|l|}{ Type of surgery } \\
\hline Mastectomy & 39 & 55.7 & & & \\
\hline Breast-conservation therapy & 31 & 44.3 & & & \\
\hline \multicolumn{6}{|l|}{ Chemotherapy } \\
\hline Yes & 57 & 81.4 & & & \\
\hline No & 13 & 18.6 & & & \\
\hline \multicolumn{6}{|l|}{ Radiotherapy } \\
\hline Yes & 69 & 98.6 & & & \\
\hline No & 1 & 1.4 & & & \\
\hline \multicolumn{6}{|l|}{ Time since diagnosis (years) } \\
\hline$\geq 1$ and $<2$ & 2 & 2.8 & & & \\
\hline$\geq 2$ and $<5$ & 15 & 21.4 & & & \\
\hline$\geq 5$ & 53 & 75.8 & & & \\
\hline Total & 70 & 100 & 84 & 100 & \\
\hline
\end{tabular}

Table 3 shows that a multivariate general linear model analysis of PCS and MCS scales was performed. It was necessary to adjust the groups with and without $\mathrm{BC}$ because they were not comparable due to the variables of age, ethnicity, marital and menopausal status. We observed there was a significant difference between the groups with and without BC regarding PCS $(p=0.009)$ and MCS $(p=0.022)$, in favor of $B C$ survivors. The best PCS $(\beta=3.51)$ and MCS $(\beta=4.32)$ scores were for the group of $B C$ survivors. Mean estimated PCS scores was significantly better for the group with BC (51.1) compared to those without cancer (47.56). When comparing MCS scores of both groups, they were different again, revealing a mean of 52.25 for women with $B C$ and 47.93 for women without cancer. Considering only the BC survivors (Table 4), we observed that marital status was significant $(p=0.019)$ between the groups, and the mean estimated MCS scores for the groups without a partner and with a partner were 39.00 and 43.77, respectively. 
Table 2 - Univariate analysis of all SF-36 dimensions of women with breast cancer and without breast cancer - Montes Claros, MG, Brazil, 2011

\begin{tabular}{|c|c|c|c|c|c|c|c|c|c|c|}
\hline \multirow[b]{2}{*}{ Dimensions } & \multicolumn{5}{|c|}{ With breast cancer } & \multicolumn{5}{|c|}{ Without breast cancer } \\
\hline & $\begin{array}{l}\text { Mean } \\
\text { (SD) }\end{array}$ & $\begin{array}{l}95 \% \\
(\mathrm{CI})\end{array}$ & Median & Min & $\operatorname{Max}$ & $\begin{array}{l}\text { Mean } \\
\text { (SD) }\end{array}$ & $\begin{array}{l}95 \% \\
\text { (CI) }\end{array}$ & Median & Min & $\operatorname{Max}$ \\
\hline $\begin{array}{l}\text { Physical } \\
\text { functioning }\end{array}$ & $\begin{array}{c}82.9 \\
(16.6)\end{array}$ & $78.9-86.9$ & 88.5 & 0 & 98.5 & $\begin{array}{c}79.8 \\
(22.3)\end{array}$ & $74.9-84.6$ & 88.5 & 18.5 & 98.5 \\
\hline Role-physical & $\begin{array}{c}69.9 \\
(22.7)\end{array}$ & $64.2-75.1$ & 80.0 & 5.0 & 80.0 & $\begin{array}{c}56.5 \\
(31.4)\end{array}$ & $49.7-63.3$ & 80.0 & 5.0 & 80.0 \\
\hline Body pain & $\begin{array}{c}79.2 \\
(17.5)\end{array}$ & $75.0-83.4$ & 82.8 & 29.8 & 98.8 & $\begin{array}{l}67.8 \\
(23.9)\end{array}$ & $62.6-73.0$ & 70.8 & 20.8 & 98.8 \\
\hline General health & $\begin{array}{c}79.8 \\
(12.3)\end{array}$ & $76.9-82.7$ & 80.8 & 28.8 & 93.8 & $\begin{array}{l}65.6 \\
(17.0)\end{array}$ & $61.9-69.3$ & 69.7 & 23.8 & 90.8 \\
\hline Vitality & $\begin{array}{c}73.9 \\
(14.4)\end{array}$ & $70.5-77.4$ & 73.8 & 23.8 & 98.8 & $\begin{array}{c}62.6 \\
(17.3)\end{array}$ & $58.8-66.3$ & 63.8 & 23.8 & 98.8 \\
\hline $\begin{array}{l}\text { Social } \\
\text { functioning }\end{array}$ & $\begin{array}{c}87.7 \\
(15.9)\end{array}$ & $83.9-91.5$ & 98.7 & 23.8 & 98.8 & $\begin{array}{c}73.7 \\
(20.9)\end{array}$ & $69.2-78.3$ & 73.8 & 11.3 & 98.8 \\
\hline Role-emotional & $\begin{array}{c}77.6 \\
(37.0)\end{array}$ & $68.8-86.5$ & 100.0 & 0 & 100.0 & $\begin{array}{c}71.4 \\
(39.1)\end{array}$ & $62.9-79.9$ & 100.0 & 0 & 100.0 \\
\hline Mental health & $\begin{array}{c}77.6 \\
(16.0)\end{array}$ & $73.8-81.4$ & 82.0 & 16.0 & 100.0 & $\begin{array}{c}67.6 \\
(17.5)\end{array}$ & $63.8-71.4$ & 68.0 & 16.0 & 96.0 \\
\hline PCS & $50.3(4.8)$ & $49.1-51.4$ & 51.4 & 35.3 & 57.6 & $47.6(7.9)$ & $45.9-49.3$ & 49.4 & 18.8 & 61.1 \\
\hline MCS & $53.9(8.6)$ & $51.9-56.0$ & 56.6 & 23.6 & 67.0 & $47.9(9.8)$ & $45.8-50.0$ & 48.5 & 20.4 & 63.7 \\
\hline
\end{tabular}

PCS=physical component summary; MCS=mental component summary; $\mathrm{SD}=$ standard deviation; $\mathrm{Cl}=$ confidence interval

Table 3 - Scales adjusted according to the socio-demographic and clinical characteristics of the women with breast cancer and without breast cancer - Montes Claros, MG, Brazil, 2011

\begin{tabular}{|c|c|c|c|c|c|c|}
\hline \multirow{2}{*}{ Parameter } & \multicolumn{2}{|c|}{ PCS } & \multirow{2}{*}{ Mean (SE) } & \multicolumn{2}{|c|}{ MCS } & \multirow{2}{*}{ Mean (SE) } \\
\hline & estimate $\beta$ (SE) & $p$-value & & estimate $\beta$ (SE) & $p$-value & \\
\hline Interceptor & $47.10(1.84)$ & 0.000 & & $45.29(2.62)$ & 0.000 & \\
\hline \multicolumn{7}{|l|}{ Group } \\
\hline With breast cancer & $3.51(1.32)$ & 0.009 & $51.10(1.09)$ & $4.32(1.87)$ & 0.022 & $52.25(1.54)$ \\
\hline Without breast cancer & ref. & & $47.56(0.81)$ & ref. & & $47.93(1.15)$ \\
\hline \multicolumn{7}{|l|}{ Age } \\
\hline $40-49$ & $2.23(1.93)$ & 0.249 & & $-0.22(2.72)$ & 0.935 & \\
\hline $50-59$ & $1.25(1.46)$ & 0.392 & & $-0.08(2.06)$ & 0.970 & \\
\hline $60-69$ & ref. & & & ref. & & \\
\hline \multicolumn{7}{|l|}{ Ethnicity } \\
\hline White & $1.26(1.25)$ & 0.314 & & $1.53(1.76)$ & 0.385 & \\
\hline Non white & ref. & & & ref. & & \\
\hline \multicolumn{7}{|l|}{ Marital status } \\
\hline Single/widow/separated & $2.07(1.19)$ & 0.085 & & $-4.02(1.68)$ & 0.018 & \\
\hline Married/living with partner & ref. & & & ref. & & \\
\hline \multicolumn{7}{|l|}{ Menopausal status } \\
\hline Pre-menopause & $1.57(1.84)$ & 0.395 & & $0.08(2.60)$ & 0.977 & \\
\hline Post-menopause & ref. & & & ref. & & \\
\hline
\end{tabular}

ref=reference category for comparisons; $\beta=$ estimated coefficient; $S E=$ standard error

Note: $(n=70)$ and $(n=84)$ 
Table 4 - Scales adjusted according to the socio-demographic and clinical characteristics of women with breast cancer - Montes Claros, MG, Brazil, 2011

\begin{tabular}{|c|c|c|c|c|c|c|}
\hline \multirow{2}{*}{ Parameter } & \multicolumn{2}{|c|}{ PCS } & \multirow{2}{*}{ Mean (SE) } & \multicolumn{2}{|c|}{ MCS } & \multirow{2}{*}{ Mean (SE) } \\
\hline & estimate $\beta$ (SE) & $p$-value & & estimate $\beta$ (SE) & $p$-value & \\
\hline Interceptor & $50.02(3.63)$ & 0.000 & & $40.22(5.72)$ & 0.000 & \\
\hline \multicolumn{7}{|l|}{ Age } \\
\hline $40-49$ & $0.91(1.69)$ & 0.594 & $50.99(2.60)$ & $-0.71(2.67)$ & 0.790 & $40.96(4.09)$ \\
\hline $50-59$ & $-1.35(1.54)$ & 0.383 & $48.73(2.29)$ & $-1.63(2.43)$ & 0.504 & $40.04(3.60)$ \\
\hline $60-69$ & ref. & & $50,08(2,17)$ & ref. & & $41,67(3.42)$ \\
\hline \multicolumn{7}{|l|}{ Chemotherapy } \\
\hline Yes & $0.45(1.68)$ & 0.791 & $49.71(2.13)$ & $-1.04(2.65)$ & 0.697 & $40.37(3.36)$ \\
\hline No & ref. & & $50.16(2.51)$ & ref. & & $41.41(3.96)$ \\
\hline \multicolumn{7}{|l|}{ Type of surgery } \\
\hline Mastectomy & $0.91(1.24)$ & 0.468 & $50.39(2.23)$ & $2.95(1.96)$ & 0.137 & $42.36(3.52)$ \\
\hline Breast conservation therapy & ref. & & $49.48(2.29)$ & ref. & & $39.42(3.61)$ \\
\hline \multicolumn{7}{|l|}{ Marital status } \\
\hline Single/separated/widow & $1.06(1.52)$ & 0.488 & $50.46(2.38)$ & $-5.77(2.40)$ & 0.019 & $39.00(3.75)$ \\
\hline Married/living with partner & ref. & & $49.40(2.22)$ & ref. & & $43.77(3.51)$ \\
\hline
\end{tabular}

ref=reference category for comparisons; $\beta=$ estimated coefficient; $S E=$ standard error Note: $(n=70)$

\section{DISCUSSION}

$\mathrm{BC}$ promotes physical, social and emotional changes in the lives of these women. The measurement of the QOL can determine the impact of the disease and the treatment promotes these life allowing patients able to mitigate these alternatives make clear changes compared with women without cancer ${ }^{(19)}$. These impacts are mostly negative and are present in all periods and even after treatment for follow up ${ }^{(21)}$. Our main objective was to compare the QOL of female BC survivors with that of women without cancer, using the SF-36 survey. Several previous studies have used the SF-36 to study the QOL of BC patients ${ }^{(17,22)}$. In our study, we observed that when analyzing all the dimensions of the SF-36 in women with and without $\mathrm{BC}$, physical functioning and social functioning had the best scores in both groups. These findings are consistent with those of previously published studies on different populations of $B C$ survivors ${ }^{(22-23)}$, which emphasized the importance of psychological support and physical therapy in reducing the need for further cancer treatment ${ }^{(24)}$. Meanwhile, vitality scored lowest in both groups in our study. This was also confirmed by another study ${ }^{(23)}$.

When we carried out the multivariate-adjusted analyses, comparing both groups, PCS and MCS scores were significantly better for the BC survivors compared with the control group, with mean PCS and MCS scores of 51 and 52 , respectively for the cancer group. The mean PCS and MCS scores observed ${ }^{(17)}$ were 50 , which is a similar result to our findings, indicating good QOL scores. Another stu$\mathrm{dy}^{(25)}$ has also recorded good QOL scores for German women with $\mathrm{BC}$, reporting a global health score that was similar to that of the general population. We observed that age showed no association with QOL. However, previous studies have identified age as a predictor of $\mathrm{QOL}^{(17,26)}$.

There is evidence that women who are satisfied with their partners report feeling better psychologically ${ }^{(15)}$. In our multivariate-adjusted analysis, BC survivors living without partners had a worse QOL (with a mean MCS score of 39.0 versus 43.7 for those living with a partner). This finding is in accordance with a study that has shown that BC survivors who had a partner had reported a better $\mathrm{QOL}^{(27)}$. Other study ${ }^{(28)}$ reported that the mean scores for QOL showed that women who were married or lived with a partner demonstrated better general health and wellbeing. On the other hand, found no association between QOL and marital status ${ }^{(17)}$.

The relationship between adjuvant chemotherapy and QOL was examined, and we observed no statistically significant difference between the groups regarding global QOL. These findings are in accordance with a study from Korea ${ }^{(29)}$. However, in a large longitudinal study ${ }^{(17)}$, reported poor QOL for women who had received systemic adjuvant therapy. These findings suggest the effects of adjuvant therapy persist many years after chemotherapy completion. There is controversy in relevant literature over whether the type of surgery received is related to $\mathrm{QOL}^{(30-31)}$. It was observed during a QOL study ${ }^{(32)}$ using SF36 , recruited 75 Brazilian female $B C$ survivors and found that, after multivariate analysis, breast conservation therapy was negatively correlated with physical aspects of QOL. In this study, the type of surgery had no impact on the global QOL. We have speculated these results might reflect a homogeneous division between the groups in the number of mastectomies $(n=39)$ and of breast conservation therapy $(n=31)$. 
The limitations of this study include the small sample size, the cross-sectional design, and the fact that the groups which were assessed had distinctive characteristics that may have positively influenced the reports of the group of cancer survivors, since most of these women represented a group that has easier access to medical care and good educational and socio-economic status.

\section{CONCLUSION}

In conclusion, our study indicates that, surprisingly, the BC survivors had a better QOL (in terms of the PCS and the MCS) when compared to women without cancer, suggesting there is a need for further research on the

\section{REFERENCES}

1. Saghir NE, Khalil MK, Eid T, Kinge AR, Charafeddine M, Geara $F$, et al. Trends in epidemiology and management of breast cancer in developing Arab countries: a literature and registry analysis. Int J Surg. 2007;5(1):225-33.

2. International Agency for Research on Cancer; World Health Organization. World Cancer Report, 2008 [Internet]. Geneva; 2009 [cited 2011 NOv 22]. Available from: http://www. iarc.fr/en/publications/pdfs-online/wcr/2008/wcr_2008.pdf

3. Meneses K, Benz R. Quality of life in cancer survivorship: 20 years later. Semin Oncol Nurs. 2010;26(2):36-46.

4. National Cancer Institute. U. S. National Institute of Health. Estimated US Cancer Prevalence Counts: who are our cancer survirvors in the U. S.? [Internet]. Bethesda; 2010 [cited 2011 Aug 27]. Available from: http://dccps.nci.nih.gov/ocs/prevalence/

5. Bosetti C, Bertuccio P, Levi F, Lucchini F, Negri E, La Vecchia C. Cancer mortality in the European Union, 1970-2003, with a joinpoint analysis. Ann Oncol. 2008;19(3):631-40.

6. Jemal A, Siegel R, Ward E, Hao Y, Xu J, Murray T, et al. Cancer statistics, 2008. Cancer J Clin. 2008;58(2):71-96.

7. Bosetti C, Malvezzi M, Chatenoud L, Negri E, Levi F, La Vecchia C. Trends in cancer mortality in the Americas, 19702000. Ann Oncol. 2005;16(5):489-511.

8. Alves CMM, Guerra MR, Bastos RR. Tendência de mortalidade por câncer de colo de útero para o Estado de Minas Gerais, Brasil, 1980-2005. Cad Saúde Pública. 2009;25(3):1693-700.

9. Boing $A F$, Vargas $S A$, Boing $A C$. Mortalidade por câncer no Brasil, 1980-1995: padrões regionais e tendências temporais. Rev Assoc Med Bras. 2007;53(4):317-22.

10. Gamarra CJ, Valente JG, Silva GA. Correção da magnitude da mortalidade por câncer de colo do útero no Brasil, 19962005. Rev Saúde Pública. 2010;44(2):629-38. subject, since most other authors have reported worse or equal QOL for BC survivors compared to women without BC. We believe that this is the first Brazilian case-control study which has used the SF-36 in order to assess breast cancer survivors and women without cancer, indicating a better QOL in all dimensions for those who have had breast cancer. Perhaps the explanation can be given by the fact that these women have found support from their families and health professionals, and have found greater meaning in life after cancer. Knowing that the multifactorial etiology has cancer, it is a need for further studies in other Brazilian regions assessing the QOL in patients with breast cancer survivors for the purpose of analysis and comparison.

11. Silva GA, Girianelli VR, Gamarra CJ, Bustamante-Teixeira MT. Cervical cancer mortality trends in Brazil, 1981-2006. Cad Saúde Pública. 2010;26(4):2399-407.

12. Rodrigues AD, Bustamante-Teixeira MT. Mortalidade por câncer de mama e câncer de colo do útero em município de porte médio da Região Sudeste do Brasil, 1980-2006. Cad. Saúde Pública. 2011;27(2):332-38.

13. Seidl EM, Zannon CM. Qualidade de vida e saúde: aspectos conceituais e metodológicos. Cad Saúde Pública. 2004;20(3):580-8.

14. Kayl AE, Meyers CA. Side-effects of chemotherapy and quality of life in ovarian and breast cancer patients. Curr Opin Obstet Gynecol. 2006;18(6):24-8.

15. Golden-Kreutz DM, Thornton LM, Wells-Di Gregorio S, Frierson GM, Jim HS, Carpenter KM, Shelby RA, et al. Traumatic stress, perceived global stress, and life events: prospectively predicting quality of life in breast cancer patients. Health Psychol. 2005;24(1):288-96.

16. Bower JE, Ganz PA, Desmond KA, Rowland JH, Meyerowitz BE, Belin TR. Fatigue in breast cancer survivors: occurrence, correlates and impact on quality of life. J Clin Oncol. 2000;18(4):743-53.

17. Ganz PA, Desmond KA, Leedham B, Rowland JH, Meyerowitz $B E$, Belin TR. Quality of life in long-term, disease-free survivors of breast cancer: a follow-up study. J Natl Cancer Inst. 2002;94(3):39-49.

18. Kornblith AB, Herndon JE 2nd, Weiss RB, Zhang C, Zuckerman EL, Rosenberg $S$, et al. Long-term adjustment of survivors of early-stage breast carcinoma, 20 years after adjuvant chemotherapy. Cancer. 2003;98(4):679-89.

19. Makluf ASD, Dias RC, Barra AA. Avaliação da qualidade de vida em mulheres com câncer da mama. Rev Bras Cancerol. 2006;52(1):49-58. 
20. Ware JE Jr, Sherbourne CD. The MOS 36-item short-form health survey (SF-36). I. Conceptual framework and item selection. Med Care. 1992;30(6):473-83.

21. Vanlemmens L, Fournier E, Boinon D, Machavoine JL, Christophe V. Quality of life of young women with early breast cancer and their partners: specific needs result in the necessity of development of specific questionnaires for the patient and the partner. Bull Cancer. 2012;99(6):685-91.

22. Yost KJ, Haan MN, Levine RA, Gold EB. Comparing SF-36 scores across three groups of women with different health profiles. Qual Life Res. 2005;14(7):1251-61.

23. Casso D, Buist DS, Taplin S. Quality of life of 5-10 year breast cancer survivors diagnosed between age 40 and 49 . Health Qual Life Outcomes. 2004;2:25.

24. Lamino DA, Mota DDCF, Pimenta CAM. Prevalence and comorbidity of pain and fatigue in women with breast câncer. Rev Esc Enferm USP[Internet]. 2011[cited 20 Jan 2];45(2):508-14. Available from: http://www.scielo.br/pdf/ reeusp/v45n2/en_v45n2a28.pdf

25. Arndt V, Merx H, Stürmer T, Stegmaier C, Ziegler H, Brenner $\mathrm{H}$. Age-specific detriments to quality of life among breast cancer quality patients one year after diagnosis. Eur J Cancer. 2004;40(5):673-80.
26. Avis NE, Crawford S, Manuel J. Quality of life among younger women with breast cancer. J Clin Oncol. 2005;23(15):3322-30.

27. Ashing-Giwa K, Ganz PA, Petersen L. Quality of life of African-American and white long-term breast carcinoma survivors. Cancer. 1999;85(2):418-26.

28. Ivanauskiene R, Kregzdyte R, Padaiga Z. Evaluation of health-related quality of life in patients with breast cancer. Medicina (Kaunas). 2010;46(5):351-9.

29. Ahn SH, Park BW, Noh DY, Nam SJ, Lee ES, Lee MK, et al. Health-related quality of life in disease-free survivors of breast cancer with the general population. Ann Oncol. 2007;18(1):173-82.

30. Engel J, Kerr J, Schlesinger-Raab A, Sauer H, Hölzel D. Quality of life following breast-conserving therapy or mastectomy: results of a 5 -year prospective study. Breast J. 2004;10(5):223-31.

31. Cohen L, Hack TF, de Moor C, Katz J, Goss PE. The effects of type of surgery and time on psychological adjustment in women after breast cancer treatment. Ann Surg Oncol. 2000;7(6):427-34.

32. Conde DM, Pinto-Neto AM, Cabello C, Santos-Sá D, Costa-Paiva L, Martinez EZ. Quality of life in Brazilian breast cancer survivors age 45-65 years: associated factors. Breast J. 2005;11(6):425-32.

\section{Acknowledgments}

This work was supported by grants from Fundação de Amparo a Pesquisa do Estado de Minas Gerais-FAPEMIG, Belo Horizonte, Brazil, and Conselho Nacional de Desenvolvimento Científico e Tecnologico-CNPq, Brazil (HMJ). 